\title{
Active and weakening MJO events in the Maritime Continent
}

\author{
Bradford S. Barrett ${ }^{1}\left[\right.$ C $\cdot$ Casey R. Densmore ${ }^{2} \cdot$ Pallav Ray $^{3}$ [D $\cdot$ Elizabeth R. Sanabia ${ }^{1}$
}

Received: 5 June 2020 / Accepted: 10 February 2021 / Published online: 5 March 2021

(C) This is a U.S. government work and not under copyright protection in the U.S.; foreign copyright protection may apply 2021

\begin{abstract}
To better understand the Madden-Julian Oscillation (MJO) in the Maritime Continent (MC), events from 1980 to 2019 were classified as active or weakening according to propagation characteristics and amplitude changes in two leading indices, the Real-time Multivariate MJO (RMM) index and Outgoing Longwave Radiation (OLR) MJO Index (OMI). Active MJO events had larger index amplitudes than weakening events, and those amplitude differences appeared at day -3 in the RMM and day -8 in the OMI and remained through day +15 in both indices (day 0 marked the day an event entered the MC). Thus, active events were stronger than weakening events as they approached and crossed the MC. To understand differences in environments between these events, composites of OLR and specific humidity were compared for each. Active MJO events had consistently more negative OLR anomalies and greater specific humidity in both the boundary layer and free troposphere than weakening MJO events. Those differences persisted during both easterly and westerly phases of the Quasi-biennial Oscillation (QBO) and during La Niña and El Niño. Active MJO events during QBO westerly winds had more specific humidity than active events did during QBO easterly winds. Finally, both active and weakening MJO events featured a diurnal cycle of lower-tropospheric specific humidity over land areas of the MC, and the amount of atmospheric moisture available to active events was consistently greater than weakening ones. These results indicate that index amplitude, OLR, and tropospheric specific humidity can all be important tools in identifying active and weakening MJO events in the $\mathrm{MC}$, including for different phases of the QBO and the El Niño-Southern Oscillation (ENSO).
\end{abstract}

Keywords Propagation of the Madden-Julian oscillation $\cdot$ Maritime continent $\cdot$ Large-scale moisture processes $\cdot$ Diurnal cycle

\section{Introduction}

The Madden-Julian Oscillation (MJO; Madden and Julian 1971, 1972) is the leading mode of tropical atmospheric variability on the subseasonal (30-90 day) timescale and has been studied extensively (see detailed reviews by Madden and Julian 1994; Zhang 2005,2013; Waliser 2006; Kim et al. 2020). However, its eastward propagation, particularly through the Maritime Continent (hereafter MC; a region roughly encompassing Indonesia, the surrounding major

Bradford S. Barrett

bbarrett@usna.edu

1 Oceanography Department, U.S. Naval Academy, 572C Holloway Rd., Annapolis, MD 21402, USA

2 MIT-WHOI Joint Program in Oceanography, Cambridge, MA, USA

3 Meteorology, Florida Institute of Technology, Melbourne, FL, USA islands, and the semi-enclosed seas; Ramage 1968), remains an active area of research with many open questions (Zhang et al. 2020).

Eastward propagation of the MJO has been linked to conditioning of the large-scale environment to the east of the region of active convection (Hendon and Salby 1994; Salby et al. 1994; Kiladis et al. 2005). Current theories suggest that one of the processes most critical to eastward propagation is boundary layer moistening. This moistening is often associated with frictional convergence in the low-level easterly flow to the east of the active convective envelope, and it is aided by increased sea surface temperatures (SSTs) caused by enhanced insolation of the convectively suppressed envelope (see the review by Li 2014). Increased boundary layer moisture to the east creates a zonal gradient in specific humidity that enables advection of mean moist static energy (MSE) by the anomalous lower-tropospheric (i.e., easterly) winds of the MJO circulation (Matthews 2000; Sperber 2003). Deep convection develops in that moist region and 
the MJO subsequently propagates eastward ( $\mathrm{Li}$ and Wang 1994; Hendon and Salby 1994; Maloney and Hartmann 1998; Kiladis et al. 2005; Benedict and Randall 2007; Maloney 2009; Hsu and Li 2012; Sobel and Maloney 2013; Kim et al. 2014; Liu et al. 2016a, b; Wang and Chen 2016; Wang et al. 2016; Zhang and Ling 2017; Zhu et al. 2017).

This moistening process seems to be the most complex in the varied orography of the MC, where eastward propagation of the MJO has been observed to be erratic and challenging to predict (Wu and Hsu 2009; Kim et al. 2016). Some MJO events propagate eastward undisturbed, others weaken or terminate, and still others end up with stalled convection centered over the major MC islands (Rui and Wang 1990; Hendon and Salby 1994; Zhang and Hendon 1997; Hsu and Lee 2005; Rauniyar and Walsh 2011; Virts et al. 2013). Sometimes the convective envelope can "detour" southward around the major MC islands and move through the oceanic region between Indonesia and Australia (Wang and Rui 1990; Wu and Hsu 2009; Kim et al. 2017; Zhang and Ling 2017). At other times, MJO propagation can be disrupted by the "barrier effect" imposed by the islands (Ahn et al. 2020; Kim et al. 2020). Numerical models have struggled to predict this complex behavior (Kim et al. 2009; Ray et al. 2011, 2012; Jiang et al. 2015), giving rise to lower skill for MJO forecasts over the MC and a so-called MJO prediction barrier (Seo et al. 2009; Vitart and Molteni 2010). The main objective of this study is to better understand the characteristics of MJO events that remain active while they move through the MC and to contrast them with MJO events that weaken while they move through the MC.

Studies advancing the moisture mode theory of the MJO (Raymond and Fuchs 2009; Sobel and Maloney 2012, 2013; Adames and Kim 2016; Fuchs and Raymond 2017; Gonzalez and Jiang 2017) highlight the critical importance of atmospheric moisture, and particularly lower-troposphere moisture in and to the east of the MC, to MJO intensity and propagation through the MC (Zhang et al. 2020). The propagation of the MJO through the MC is tied to above-normal tropospheric specific humidity within the MJO active envelope (Stachnik et al. 2015). However, above-normal moisture has been found in the MC for both propagating and non-propagating MJO events (DeMott et al. 2018). Given these questions, in this study, MJO intensity and moisture are examined in more detail, including in both horizontal structures and vertical cross-sections. The diurnal cycle of moisture is also examined, since disruption of MJO eastward propagation in the MC has been found associated with a strengthening of the diurnal cycle of convection (Qian 2008; Hagos et al. 2016). Indeed, in MJO events that fail to propagate across the $\mathrm{MC}$, above-normal daytime convection over land acts to suppress nocturnal convection over water. This reduction in nocturnal convection tends to favor MJO weakening and stagnation because it interrupts the circulations that are one of the primary mechanisms for moistening and propagation of the convection over the MC (Peatman et al. 2014; Hagos et al. 2016; Madja and Yang 2016; Zhang and Ling 2017; Ling et al. 2019).

Finally, MJO intensity and propagation over the MC are linked to other large-scale modes of variability. For example, MJO propagation is favored during the easterly phase of the Quasi-biennial Oscillation (QBO) (Zhang and Zhang 2018; Densmore et al. 2019) and during the La Niña phase of the El Niño-Southern Oscillation (ENSO) (Hendon et al. 2007; Tang and Yu 2008; Kerns and Chen 2016). However, the degree to which these multi-scale processes interact and project onto tropospheric moisture for MJO events over the MC remains an open question. Thus, moisture characteristics will also be examined during different modes of QBO and ENSO, to examine the degree to which those modes affect moisture for active and weakening MJO events over the MC. The rest of this study is organized as follows: data and methods are presented in Sect. 2; results are presented in Sect. 3; and conclusions are presented in Sect. 4.

\section{Data and methods}

In this study, MJO intensity and location were quantified first using the Wheeler and Hendon (2004) Real-time Multivariate MJO (RMM) index, which is freely available from the Bureau of Meteorology of Australia (www.bom.gov.au/clima te/mjo/). The RMM index identifies the strength and location of the enhanced convective envelope of the MJO (hereafter the "active envelope") from an empirical orthogonal function (EOF) analysis of outgoing longwave radiation (OLR) and lower- $(850 \mathrm{hPa})$ and upper-troposphere $(200 \mathrm{hPa})$ zonal winds from $15^{\circ} \mathrm{S}$ to $15^{\circ} \mathrm{N}$. The RMM index is used operationally because of its real-time availability and simplicity of interpretation, but it has several known shortfalls (Straub 2013; Liu et al. 2016a, b). In particular, higher-frequency (synoptic-scale) variability can project onto the RMM index (Roundy et al. 2009), which may cause the index to indicate westward MJO propagation or other uncharacteristic features. In addition, the RMM index exhibits a bias toward zonal wind observations over OLR observations, meaning large-scale convection and precipitation associated with the MJO may not project as well onto the index (Straub 2013; Ventrice et al. 2013). To account for those biases, MJO location and intensity were also quantified using a second index, the OLR MJO index (OMI; Kiladis et al. 2014), which is freely available for download from the NOAA Earth System Research Laboratory (https://www.esrl.noaa.gov/psd/mjo/ mjoindex/omi.1x.txt). The OMI is based on an EOF analysis of bandpass-filtered OLR from $20^{\circ} \mathrm{S}$ to $20^{\circ} \mathrm{N}$ and projects MJO amplitude and geographic position onto a phase space in a manner similar to the RMM. The OMI thus quantifies 
the MJO based on its convective anomalies, which is an advantage over the RMM index. However, because of its focus on OLR, the OMI can sometimes miss MJO circulation features (Kiladis et al. 2014). To account for these strengths and weaknesses, the MJO in this study will be examined using both indices.

For all seasons from 1980 to 2019, 160 MJO events (spanning 1635 MJO days) were identified that progressed through RMM phases 4 and 5 (those phases approximately correspond to the active envelope crossing the MC; WH04)
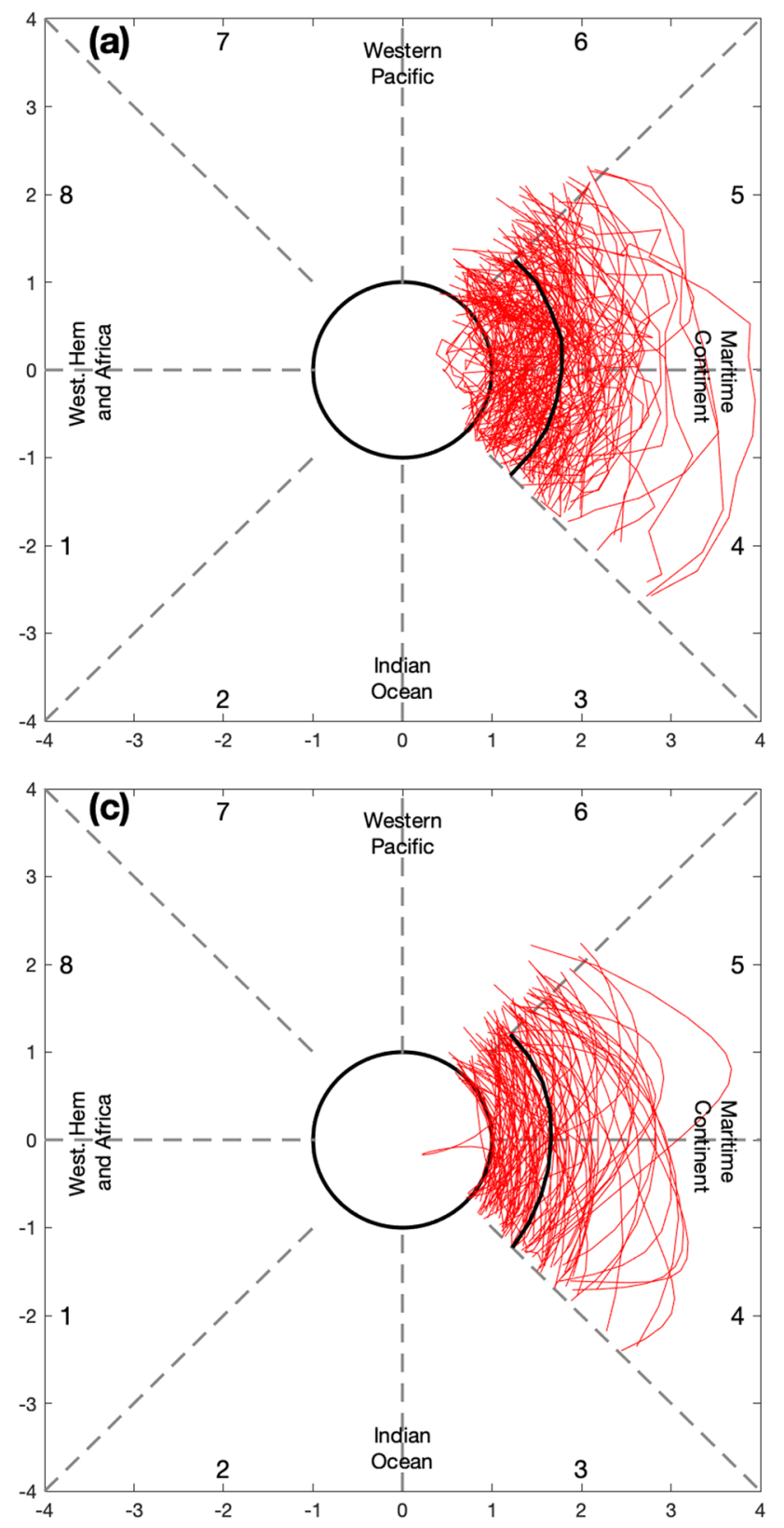

Fig. 1 Progression (red curves) of a 120 active and b 40 weakening MJO events in the RMM index over the Maritime Continent through phases 4 and 5 from 1980 to 2019. Curves in (c, d) are as in (a, b) but
(Fig. 1, top). Over the same period, $138 \mathrm{MJO}$ events that crossed the MC (spanning 1249 MJO days) were identified using the OMI (Fig. 1, bottom). To be considered an event in either analysis, the MJO had to cross from phase 3 into phase 4 with an index amplitude greater than or equal to 1.0 and had to demonstrate counterclockwise progression in its respective (RMM or OMI) phase space on at least $65 \%$ of the days it was in phases 4 and 5 . This propagation constraint, used by Densmore et al. (2019), was imposed to retain the greatest number of $\mathrm{MJO}$ events while excluding
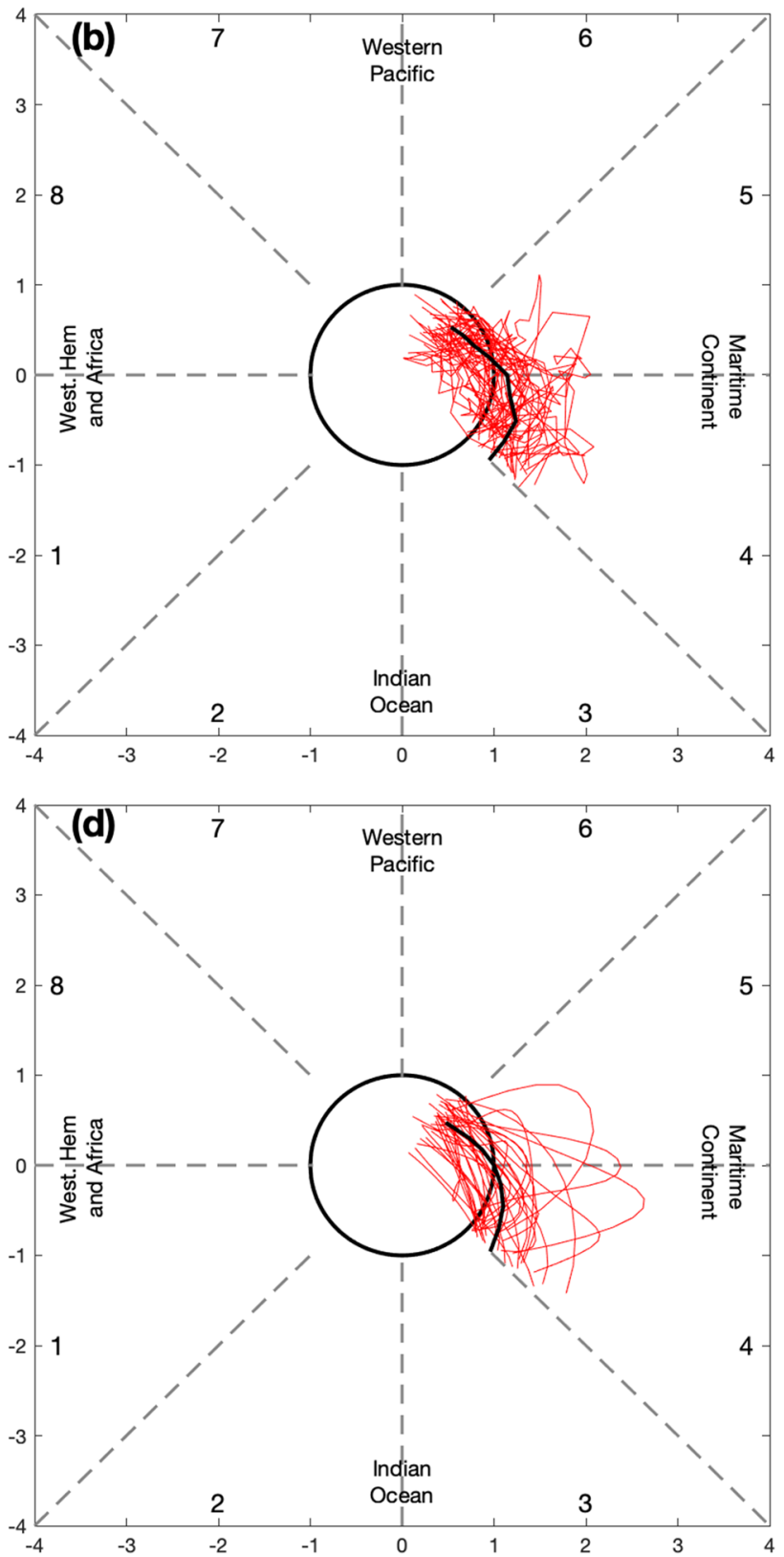

for the 101 active and 37 weakening events in the OMI index, respectively. Black curves in each panel indicate mean progression of each type of event 
those that featured stationary periods or that moved substantially clockwise in their respective phase space (Jones et al. 2015; LaFleur et al. 2015). Active MJO events for the MC were defined as those that not only met the amplitude and propagation criteria above but that also exited phase 5 with an index amplitude greater than 1.0 (Fig. 1a, c). Weakening $\mathrm{MJO}$ events for the MC were defined as those that crossed into phase 4 with an index amplitude greater than 1.0 (similar to the active events) but that weakened and exited phase 5 with an index amplitude less than 1.0 (Fig. 1b, d).

It is important to note that these classifications of active and weakening MJO events are based on the amplitudes of the respective indices as the events entered phase 4 and exited phase 5 . The amplitudes of $29 \%$ of the active events weakened by more than 0.3 while they crossed phases 4 and 5, and the amplitudes of $90 \%$ of the weakening events weakened by more than 0.3 while they crossed phases 4 and 5. However, the results presented below did not change meaningfully when active and weakening MJO events were filtered by this amplitude-change threshold, so the magnitude of amplitude change was not considered when defining active and weakening events.

To study differences in the large-scale environment, composite standard anomalies of specific humidity $(q)$ from the European Center for Medium-range Weather Forecasts (ECMWF)'s fifth generation climate reanalysis dataset (ERA5; Hersbach et al. 2020) were calculated for active and weakening events over the MC from 1980 to 2019 . Hourly values of specific humidity were downloaded at a horizontal grid spacing of $0.25^{\circ}$ by $0.25^{\circ}$ from pressure levels between 1000 and $100 \mathrm{hPa}$. Specific humidity was analyzed at 0000 and 1200 UTC both separately and together (with those hours combined via simple arithmetic mean), to account for possible influences from the diurnal convective cycle. Because the differences in specific humidity between active and weakening MJO events were similar at 0000 and 1200 UTC, results from the combination of both hours are presented here. Daily OLR data from 1980 to 2019 were downloaded from the NOAA Physical Sciences Laboratory at a horizontal grid spacing of $2.5^{\circ}$ by $2.5^{\circ}$ (Liebmann and Smith 1996). Gridded anomalies of $q$ and OLR were then smoothed using a 5-day running mean to suppress high-frequency variations.

Daily standard anomalies from 1980 to 2019 were calculated by subtracting the long-term mean (calculated using a 31-day window centered on each day) from the daily value, then dividing that result by the long-term standard deviation (calculated in the same way as the longterm mean). For example, a daily standard anomaly of specific humidity $\hat{q}_{i}$ at day $i$ was calculated as: $\hat{q}_{i}=\frac{q_{i, j}-\mu_{j}}{\sigma_{j}}$

where $q_{i, j}$ is the specific humidity at date $i$ corresponding to the day of year $j$ ( $j$ is an index ranging from 1 to 365 , where January 1 corresponds to $j=1$, December 31 corresponds to $j=365$, and on leap years February 29 is included with February 28$), \mu_{j}$ is the long-term (1980-2019) mean specific humidity for the 31-day window centered on day of year $j$, and $\sigma_{j}$ is the long-term standard deviation of specific humidity corresponding to the long-term mean at day of year $j$.

Vertical cross sections of specific humidity from 1000 to $100 \mathrm{hPa}$ were averaged meridionally over $10^{\circ} \mathrm{S}-10^{\circ}$ $\mathrm{N}$ to examine the vertical structure of specific humidity anomalies. Daily lagged anomalies from day -15 to +15 were defined relative to the day the MJO event crossed into phase 4 in RMM and OMI phase space. To account for possible seasonality, two sets of composite anomalies of specific humidity and OLR were created and analyzed: one for the whole year, and one excluding June-August. However, no meaningful statistically significant differences in the standard anomalies of OLR or specific humidity between the seasons were found (e.g., active events resembled each other in all seasons, and weakening events also resembled each other in all seasons). Thus, composites for the entire year are presented. Finally, anomalies of OLR and specific humidity were tested for significance using the Welch's $t$-test, with the null hypothesis being that composite anomalies at each lagged day and grid point for active and weakening events were not statistically different from one another. The phase of the QBO on the day the MJO crossed into RMM or OMI phase 4 was determined following Densmore et al. (2019), allowing for a binning of active and weakening MJO events by periods of easterly and westerly mid-stratospheric QBO winds. The phase of the QBO was determined using an EOF analysis of daily stratospheric (100-10 hPa) zonal winds, with easterly and westerly QBO winds in this study corresponding to the "QBOEM" and "QBOWM" categories, respectively, in Densmore et al. (2019). Binning of active and weakening MJO events by ENSO phase was done similarly, where ENSO phase was defined using the oceanic Niño index (ONI; Kousky and Higgins 2007). Events were classified as El Niño or La Niña in the ONI when SST anomalies from the Niño-3.4 region $\left(5^{\circ} \mathrm{S}-5^{\circ} \mathrm{N}, 120^{\circ}-170^{\circ} \mathrm{W}\right)$ were greater than $0.5^{\circ} \mathrm{C}$ or less than $-0.5^{\circ} \mathrm{C}$ for a period of 5 or more continuous months, respectively (following Lee et al. 2014). The ONI SST data were obtained from the NOAA/Climate Prediction Center (CPC; http://origi n.cpc.ncep.noaa.gov/products/analysis_monitoring/ensos tuff/ONI_v5.php). 


\section{Results}

\subsection{Active and weakening MJO events}

From 1980 to 2019, 160 MJO events were identified over the MC (Fig. 1; Table 1) that entered RMM phase 4 with amplitude greater than 1.0. Of those, 120 exited phase 5 with amplitude greater than 1.0 (and thus were classified as active; Fig. 1a) and 40 exited phase 5 with amplitude less than 1.0 (and thus were classified as weakening; Fig. 1b). Of the 160 events that crossed into RMM phase 4 with amplitudes greater than $1.0,75 \%$ were classified as active and the other $25 \%$ as weakening. That ratio of active to weakening events was similar for the OMI. In that index, 138 events were identified, of which 101 (or 73\%) were classified as active (Fig. 1c) and 37 (or 27\%) were classified as weakening (Fig. 1d). This ratio of active to weakening events stayed relatively consistent throughout the year in both indices, with the exception of boreal summer (June-August; JJA) in the RMM (Table 1). During boreal winter (December-February;

Table 1 Number of active and weakening MJO events in the RMM and OMI indices from 1980 to 2019, for the entire year and for each 3-month season

\begin{tabular}{lcclll}
\hline & RMM & & & OMI \\
\cline { 2 - 3 } \cline { 5 - 6 } \cline { 5 - 6 } & Active events & $\begin{array}{c}\text { Weaken- } \\
\text { ing events }\end{array}$ & Active events & $\begin{array}{c}\text { Weaken- } \\
\text { ing events }\end{array}$ \\
\hline All seasons & 120 & 40 & 101 & 37 \\
DJF & 36 & 10 & 31 & 8 \\
MAM & 35 & 11 & & 28 & 12 \\
JJA & 15 & 13 & 24 & 10 \\
SON & 34 & 6 & 18 & 7 \\
\hline
\end{tabular}

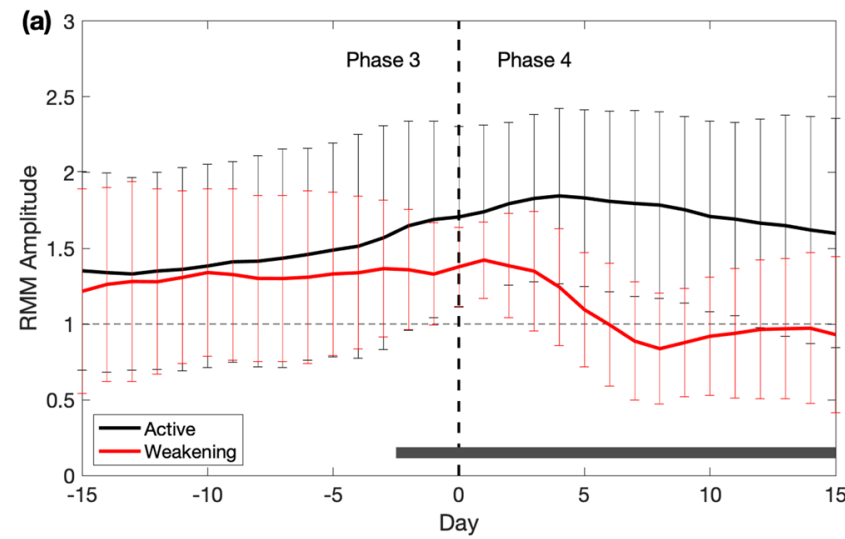

Fig. 2 Mean (solid curve) and standard deviation (vertical bars) of a RMM and b OMI amplitudes 15 days before to 15 days after active and weakening MJO events cross phase 4 . Days with statistically sig-
DJF), $78 \%$ of the $46 \mathrm{MJO}$ events in the RMM index were classified as active; in boreal spring (March-May; MAM), $76 \%$ of the 46 events were classified as active; and in boreal autumn (September-November; SON), $85 \%$ of the 40 events were classified as active. In boreal summer (JJA), however, only $54 \%$ of the $28 \mathrm{MJO}$ events were classified as active in the RMM index. The percentage of active events in the OMI index in boreal winter, spring, summer, and winter was constant throughout the year, at $79 \%, 70 \%, 70 \%$, and $72 \%$, respectively. The differences in frequency of active and weakening MJO events in JJA in the RMM are likely at least partly due to the seasonal transition to, and interaction between, the MJO and the boreal summer intraseasonal oscillation (BSISO) (Madden 1986; Wang and Rui 1990; Wang and Xie 1997; Lawrence and Webster 2002; Kikuchi et al. 2012; Jiang et al. 2015). The BSISO often exhibits northeastward propagation that may not be captured well by the RMM index (Lee et al. 2013; Straub 2013).

The extent to which the index amplitude differs between active and weakening MJO events is captured in a time series from day -15 to +15 (Fig. 2), again centered on when the MJO entered phase 4 of the RMM and OMI indices. In the RMM index, index amplitudes for active events were slightly greater than weakening events as much as 15 days before crossing into the MC (Fig. 2a), and the difference in amplitude gradually increased, peaking around day +8 . Statistically significant differences (at the 95th percentile using a two-sample Kolmogorov-Smirnov test) in RMM amplitude began at day -3 and continued through day +15 (Fig. 2a). At day 0, active MJO events had a mean amplitude of 1.70 and weakening MJO events had a mean amplitude of 1.38 (Table 2). Similar differences in amplitude were also noted in the OMI (Fig. 2b), where amplitudes became statistically significantly different from one another at day -8 and peaked around day +12 . At day 0 , active events had a

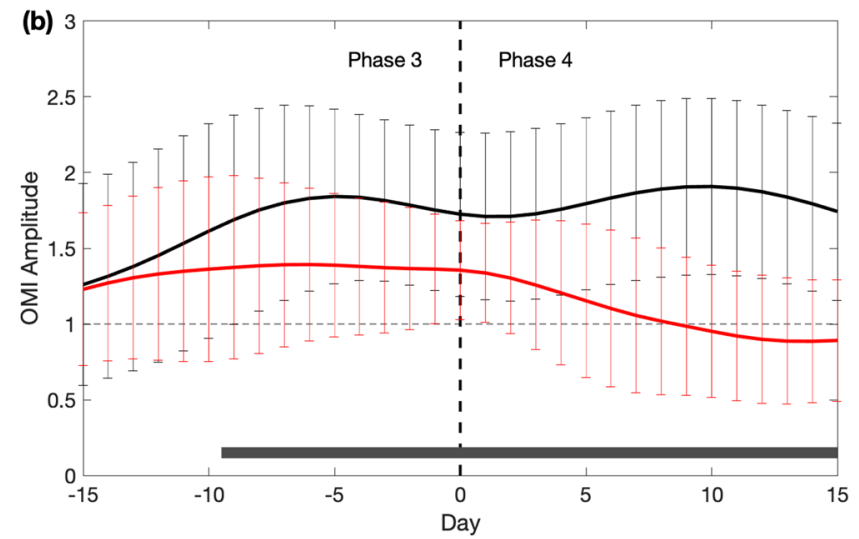

nificant differences between index amplitudes are indicated by the dark bar across the bottom of each panel 
Table 2 Average index amplitude on day 0 (when the MJO event entered the MC) for active and weakening MJO events in both the RMM and OMI indices from 1980 to 2019

\begin{tabular}{llllll}
\hline & Active & & & \multicolumn{2}{l}{ Weakening } \\
\cline { 2 - 3 } \cline { 5 - 6 } \cline { 5 - 6 } & $\begin{array}{l}\text { Day 0 ampli- } \\
\text { tude }\end{array}$ & $\begin{array}{l}\text { Sample size } \\
(n)\end{array}$ & & $\begin{array}{l}\text { Day 0 ampli- } \\
\text { tude }\end{array}$ & $\begin{array}{l}\text { Sample } \\
\text { size }(n)\end{array}$ \\
\hline RMM Index & 1.7071 & 120 & 1.3779 & 40 \\
OMI Index & 1.7252 & 101 & & 1.3554 & 37 \\
\hline
\end{tabular}

Sample size indicated by $n$

mean OMI amplitude of 1.72 and weakening events had an OMI amplitude of 1.35 (Table 2). Although amplitudes of active and weakening MJO events were statistically significantly different, the large spread at day 0 (seen in overlapping standard deviations in Fig. 2) indicates that RMM and OMI amplitudes alone are not a good factor to distinguish between active and weakening MJO events across the MC. That is, just because a particular MJO event has a large index amplitude as it enters the MC does not guarantee it will successfully cross it, and just because an MJO event has a weak index amplitude does not guarantee it will weaken.

\subsection{MJO amplitude and OLR}

To identify additional differences between active and weakening MJO events, composites of OLR were examined over the $\mathrm{MC}$ and surrounding region. Because of the differences in how the EOFs in each index weight OLR, composite anomalies of OLR were analyzed for both RMM and OMI. However, OLR composites for each index were very similar, so only composites based on the RMM are presented here. Each day from -15 to +15 was analyzed, and composite mean OLR on days $-8,0$, and +8 are presented. On day -8 , the MJO convective envelope in both active (Fig. 3a) and weakening (Fig. 3b) events was seen as a region of negative OLR anomalies approximately $4000 \mathrm{~km}$ in horizontal extent centered along the equator near $80^{\circ} \mathrm{E}$. The active $\mathrm{MJO}$ events had slightly stronger OLR anomalies (Fig. 3c) than weakening events, both over the eastern Indian Ocean (up to - 0.3 standard anomalies) and the MC (up to +0.3 standard anomalies). These anomalies indicate slightly more convection in the active envelope and more subsidence in the suppressed envelope, and those differences were statistically significant at the 95\% level. At day 0, the convection in both active (Fig. 3d) and weakening (Fig. 3e) events was centered near $100^{\circ} \mathrm{E}$, and the active events had statistically significantly greater coverage and intensity of convection over much of the eastern Indian Ocean and MC (approximately $80^{\circ}-140^{\circ}$ E) than did weakening events (Fig. 3f). Thus, OLR anomalies were more negative for active than weakening events (by up to - 0.6 standard anomalies, slightly more than at day -8$)$. By day +8 , the greatest OLR difference between active and weakening MJO events was centered between $125^{\circ}$ and $150^{\circ} \mathrm{E}$. Those anomalies were negative (up to -0.8 standard anomalies), indicating the convection in active MJO events was now much stronger than in weakening MJO events.

These differences suggest that the spatial coverage and strength of the convection in the eastern Indian Ocean (at day -8 and especially day 0 ) may be an important discriminator between active and weakening events prior to those events entering the MC. Moreover, they indicate that the strength of the convection over the MC may indicate whether a particular MJO event is active or weakening at day 0 . However, the composite anomaly differences were small, particularly at day -8 , indicating that OLR, which provides a top-level view of convection coverage
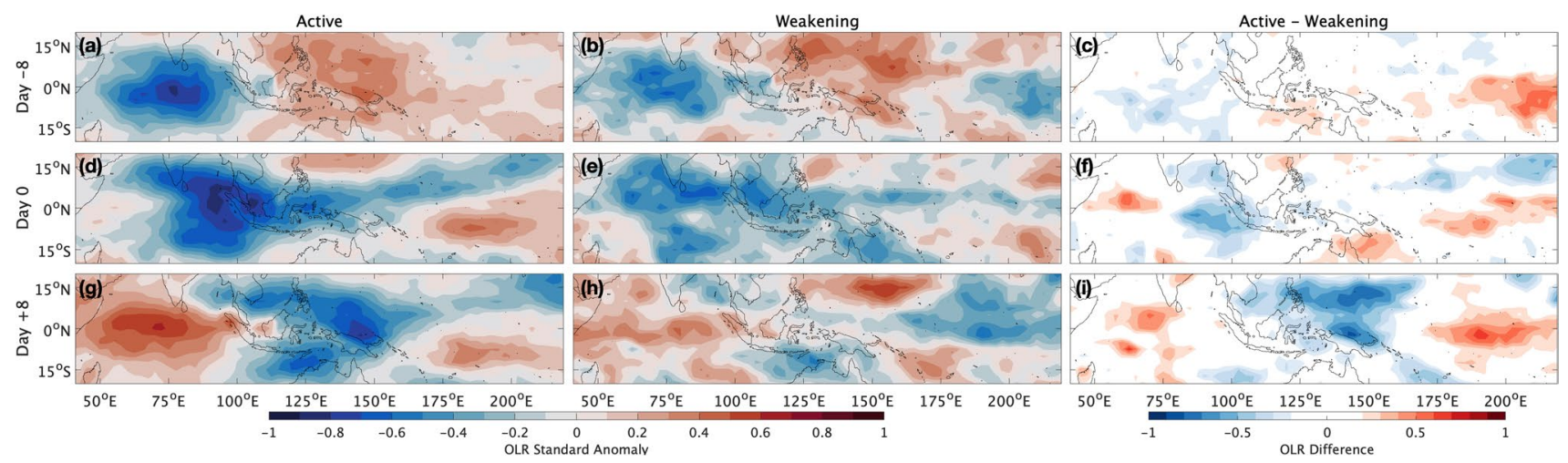

Fig. 3 Composite standard anomalies of outgoing longwave radiation for $\mathbf{a}-\mathbf{c}$ day $-8, \mathbf{d}-\mathbf{f}$ day 0 , and $\mathbf{g}-\mathbf{i}$ day +8 . Active MJO events are shown in the left column (a, $\mathbf{d}$ and $\mathbf{g})$; weakening MJO events are shown in the middle column (b, e and $\mathbf{h}$ ); and the difference in OLR (active minus weakening) are shown in the right column (c, $\mathbf{f}$ and $\mathbf{i}$ ).
All data are from NOAA Physical Sciences Laboratory, daily from 1980 to 2019 . Only differences that are statistically significant at the 95\% confidence level are shown in (c, $\mathbf{f}$ and $\mathbf{i})$. Units are dimensionless standard anomalies 
and intensity across a region, may not fully capture the environmental differences between active and weakening MJO events.

\subsection{MJO activity and specific humidity}

To further explore the environmental differences between active and weakening MJO events (beyond index amplitude and OLR horizontal composites), horizontal composites and vertical cross sections of specific humidity were examined.

\subsubsection{Maritime Continent}

At day -8 , both active and weakening MJO events had positive specific humidity anomalies throughout the troposphere (1000-200 $\mathrm{hPa}$ ) between $60^{\circ}$ and $100^{\circ} \mathrm{E}$ associated with the MJO convective envelope (Fig. 4a, b). However, active events featured greater specific humidity (by up to +0.3 standard anomalies) than weakening events (Figs. 4a-c, 5a-c), including in the lower troposphere "moisture foot" over the MC (1000-700 hPa between $100^{\circ}$ and $\left.150^{\circ} \mathrm{E}\right)$. Moreover, weakening events featured a stronger dry region between $300-500 \mathrm{hPa}$ (standard anomalies of
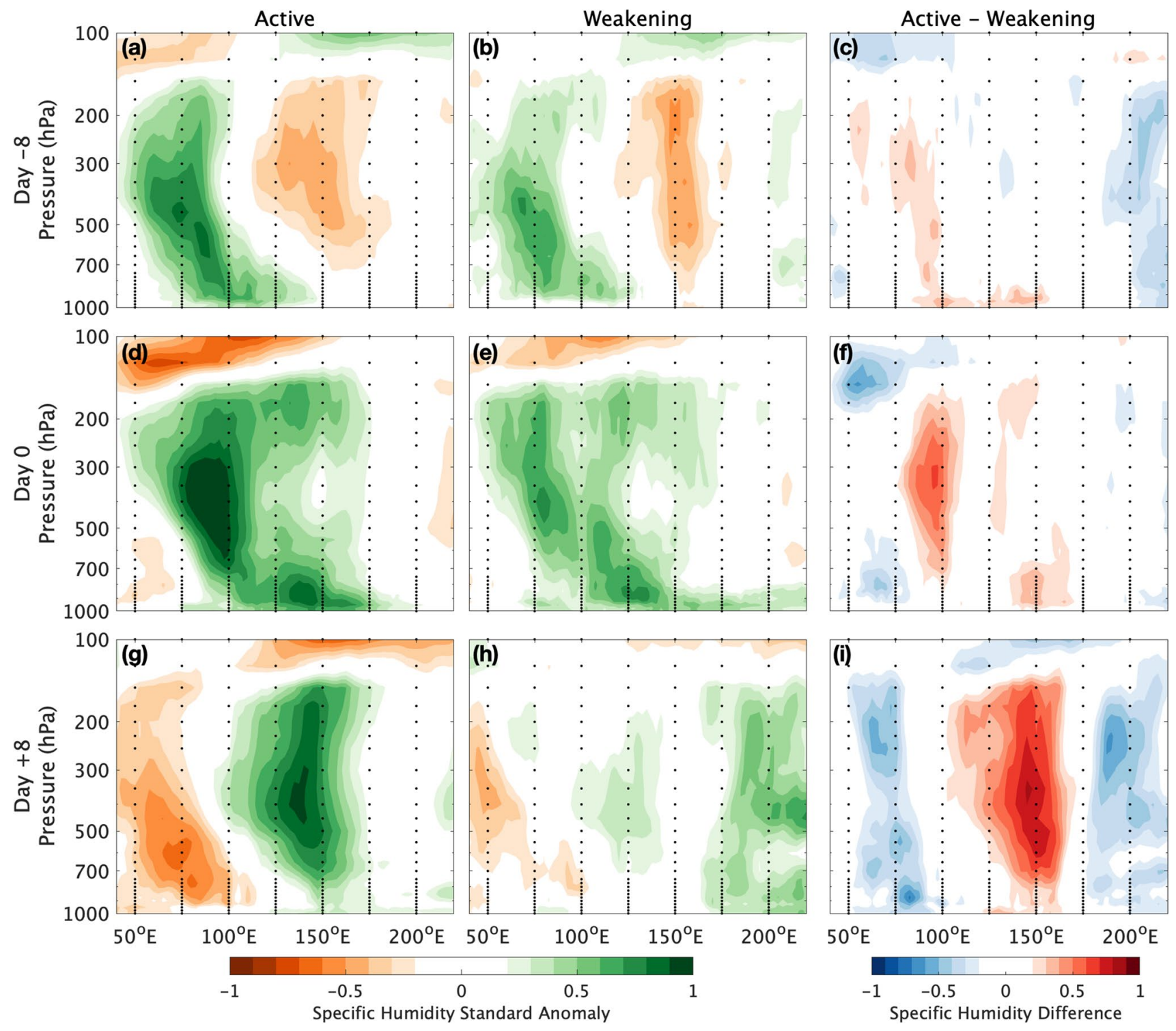

Fig. 4 Composite vertical cross sections of standard anomalies of specific humidity (shaded) for $\mathbf{a}-\mathbf{c}$ day $-8, \mathbf{d}-\mathbf{f}$ day 0 , and $\mathbf{g}-\mathbf{i}$ day +8 . Composites are averaged over $10^{\circ} \mathrm{S}-10^{\circ} \mathrm{N}$, and dots indicate vertical pressure levels. Active MJO events are shown in the left column (a, d and $\mathbf{g}$ ); weakening MJO events are shown in the middle column (b, e and $\mathbf{h}$ ), and the difference in specific humidity (active minus weakening) are shown in the right column (c, $\mathbf{f}$ and i). Only differences that are statistically significant at the $95 \%$ confidence level are shown in (c, f and i). All data are from ERA5 1980 to 2019, and values at 0000 and 1200 UTC are averaged 


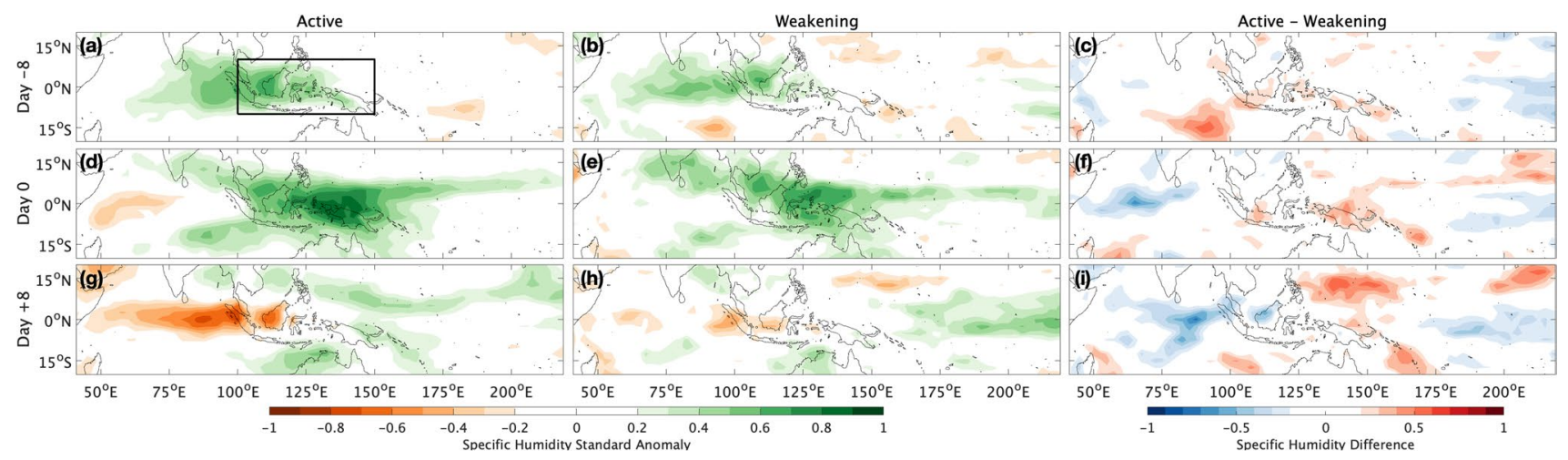

Fig. 5 As in Fig. 3, but for composite spatial plots of standard anomalies of lower-troposphere (1000-700 hPa) specific humidity (shaded) for active and weakening MJO events. Only differences that are sta-

-0.2 ) near $155^{\circ} \mathrm{E}$ than active events did (Fig. 4a-c). At day 0 , both active and weakening MJO events had positive specific humidity anomalies over the entire troposphere (1000-200 hPa) associated with the core of the convective envelope between $70^{\circ}$ and $100^{\circ} \mathrm{E}$ (by up to +0.5 standard anomalies) and between $125^{\circ}$ and $170^{\circ} \mathrm{E}$ (by up to +0.3 standard anomalies) associated with the eastern edge of the convective envelope. During active events, the atmosphere was thus more humid than during weakening events (Fig. 4d-f). This increased humidity was also evident in the lower troposphere at day 0 from the eastern Indian Ocean eastward to Borneo (Fig. 5d-f). At day + 8, active events had greater positive specific humidity anomalies in the lower, middle, and upper troposphere associated with the convective envelope (by up to +0.8 standard anomalies between 1000 and $150 \mathrm{hPa}$ ) than did weakening events (Figs. $4 \mathrm{~g}-\mathrm{i}$, $5 \mathrm{~g}-\mathrm{i}$ ). Active events also had stronger suppression at day +8 , with negative specific humidity anomalies on either side of the active envelope $\left(50^{\circ}-100^{\circ} \mathrm{E}\right.$ and $\left.175^{\circ}-225^{\circ} \mathrm{E}\right)$ (Fig. $\left.4 \mathrm{i}\right)$.

These results show that active MJO events across the MC tended to be more humid in both the convective envelope and the moisture foot than weakening MJO events. These differences in specific humidity suggest that humidity may be useful to distinguish MJO events that remain active from events that weaken. This is particularly so if specific humidity anomalies are examined in tandem with index amplitude and OLR anomalies. However, other large-scale modes of atmospheric variability, particularly the QBO and ENSO, are also known to affect MJO propagation in the MC. Therefore, differences in specific humidity are further stratified by phase of those modes and are examined in the next section.

\subsubsection{QBO and ENSO}

When mid-stratospheric winds (at approximately $70 \mathrm{hPa}$ ) were either westerly (Fig. 6) or easterly (Fig. 7), active MJO tistically significant at the $95 \%$ confidence level are shown in (c, f, and i). The box in (a) indicates the spatial average for diurnal cycle of lower-troposphere specific humidity presented in Fig. 10

events were consistently more humid (standard anomalies up to +1.0 over the MC) than weakening events (Figs. 6, 7 ). The area of greater tropospheric humidity was seen on day -8 over the Indian Ocean (Figs. 6a, 7a), on day 0 in the region from $80^{\circ}$ to $110^{\circ} \mathrm{E}$ (Figs. $6 \mathrm{~d}, 7 \mathrm{~d}$ ), and over the MC on day +8 (Figs. $6 \mathrm{~g}, 7 \mathrm{~g}$ ). This result agrees well with the findings in the previous section (Figs. 4, Fig. 5) and indicates that active MJO events are more humid than weakening MJO events for both QBO easterly and westerly phases. This result was present in both extended winter (November-March) and for the entire year. Nevertheless, some important differences in moisture for different QBO phases were seen. For example, when mid-stratospheric winds were from the west (a condition that generally favors weaker MJO events and less-likely propagation through the MC; see Densmore et al. 2019), active events had greater tropospheric specific humidity (Fig. 6) than active events during mid-stratospheric easterly winds (Fig. 7). That humidity difference appeared over the eastern Indian Ocean on day -8 and the $\mathrm{MC}$ on days 0 and +8 , and it suggests that tropospheric humidity is especially important for $\mathrm{MJO}$ events that propagate through the MC during QBO westerly winds. Moreover, the difference in specific humidity between active and weakening MJO events during midstratospheric easterly QBO winds was smaller than it was during westerly QBO winds. Weakening MJO events during westerly QBO winds had lesser tropospheric specific humidity on day -8 between $120^{\circ}$ and $160^{\circ} \mathrm{E}$ and from 1000 to $100 \mathrm{hPa}$ (Fig. 6b) than weakening events during easterly QBO winds (Fig. 7b). Additionally, weakening MJO events were more humid during QBO easterly winds than they were during QBO westerly winds (between $100^{\circ}$ and $120^{\circ} \mathrm{E}$ and 500-200 hPa; compare Fig. 7c with Fig. 6c). These results suggest that active MJO events that cross the MC during the QBO westerly phase need more moisture throughout the troposphere than active MJO events during the QBO easterly 

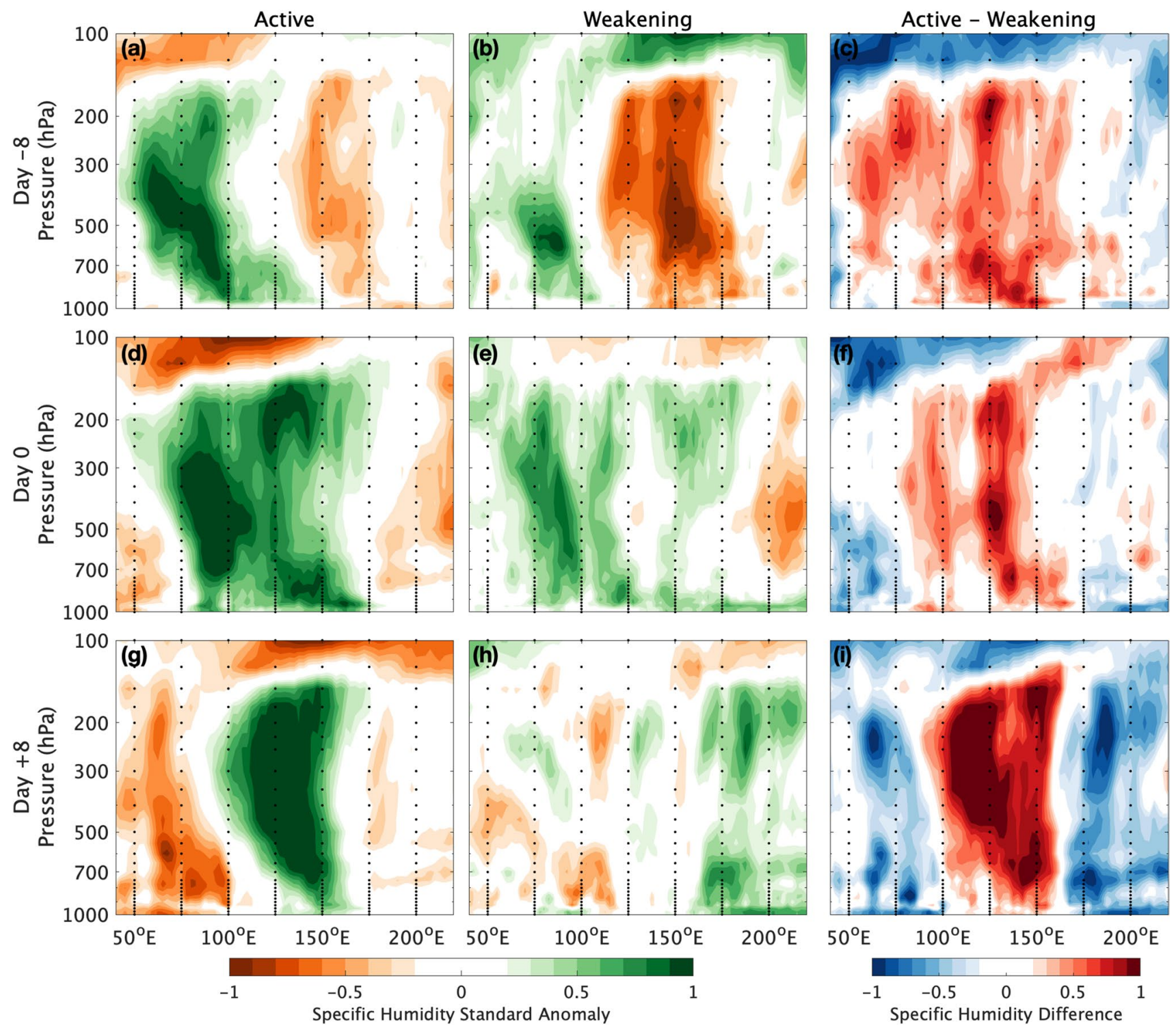

Fig. 6 As in Fig. 4, but for active and weakening MJO events during QBO westerly winds

phase. They also suggest that tropospheric humidity over the Indian Ocean and MC may be an important discriminator between active and weakening MJO events during QBO westerly winds, but not so much during QBO easterly winds.

Active MJO events during El Niño conditions had greater tropospheric humidity between $80^{\circ}$ and $120^{\circ} \mathrm{E}$ at days -8 and 0 (Fig. 8a, d) and over the lower troposphere (between 1000 and $700 \mathrm{hPa}$ ) at days 0 and +8 (Fig. 8d, g) than did weakening MJO events. Moreover, active MJO events during La Niña conditions also had consistently greater tropospheric humidity in both the convective envelope and moisture foot regions than did weakening MJO events on days -8 and 0 (Fig. 9c, f). These differences in specific humidity were similar to the results for all MJO events (Fig. 4), indicating that active MJO events are more humid than weakening MJO events in both El Niño and La Niña. It is important to note that both active and weakening MJO events during El Niño were substantially drier (by up to 1 standard anomaly) than those events during La Niña over much of the $\mathrm{MC}\left(100^{\circ}-120^{\circ} \mathrm{E}\right)$ between 700 and $200 \mathrm{hPa}$. The drier troposphere over the MC and adjacent western Pacific during El Niño than during La Niña agrees with studies that have found that MJO intensity is larger, and eastward propagation is more likely, during La Niña than during El Niño (Lau and Chan 1986; Li and Smith 1995; Zhang and Gottschalck 2002; Hendon et al. 2007; Pohl and Matthews 2007; Pillai and Chowdary 2016; DeMott et al. 2018). However, the particular details are complex and seem to depend not just on ENSO phase but on both the location of the warm pool and the change in ENSO index amplitude (Chen et al. 

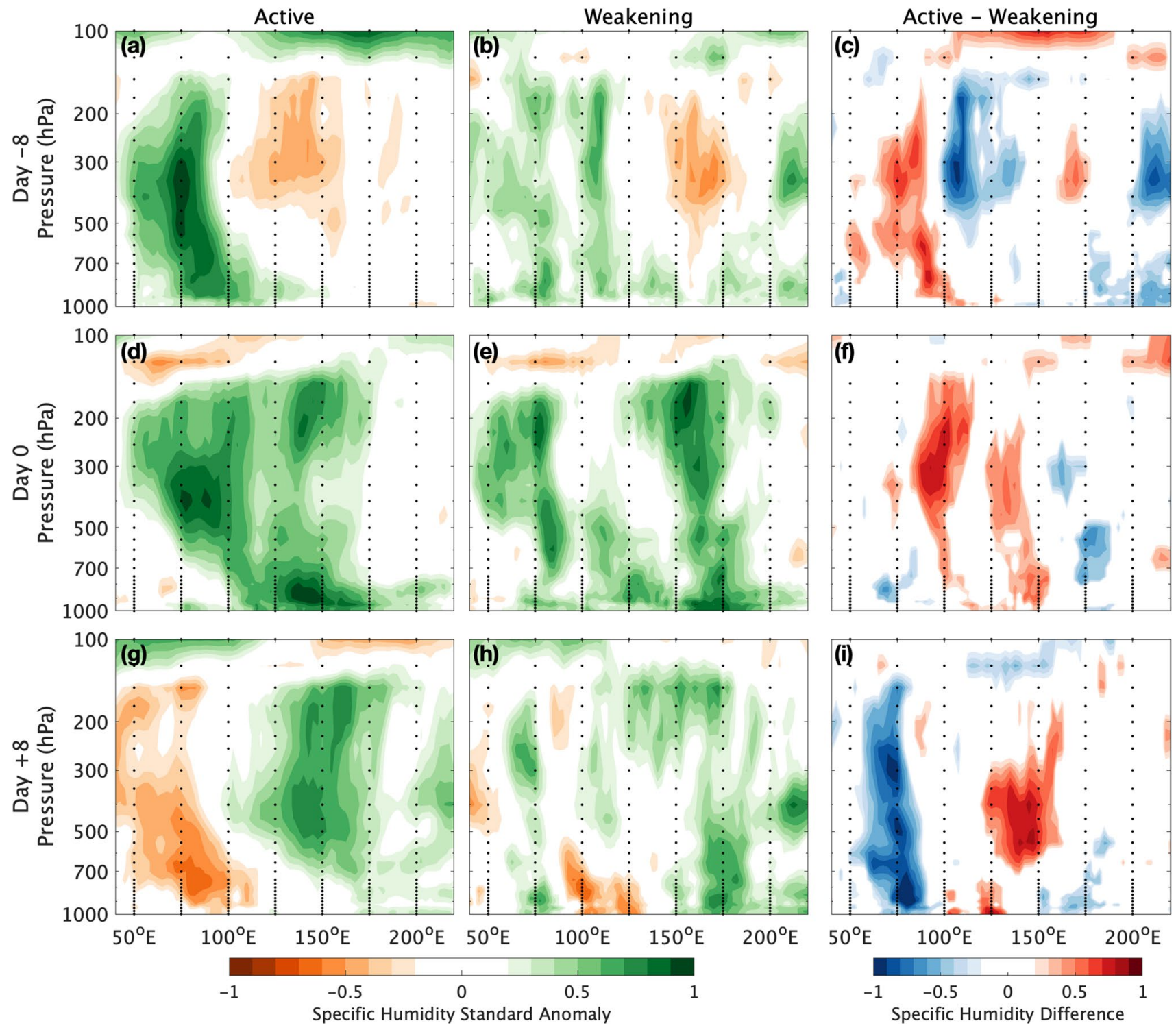

Fig. 7 As in Fig. 4, but for active and weakening MJO events during QBO easterly winds

2016; Suematsu and Miura 2018; Wu and Song 2018; Wei and Ren 2019).

\subsubsection{Diurnal cycle}

In addition to horizontal differences in the structure and amplitude of OLR, and horizontal and vertical differences in specific humidity, differences in the diurnal cycle of specific humidity in the lower troposphere between active and weakening MJO were examined in hourly values of specific humidity from ERA5. It is important to note here that while many MJO studies have examined the diurnal cycle of precipitation, particularly comparing over-land to over-water convection (e.g., Tian et al. 2006; Rauniyar and Walsh 2011; Oh et al. 2012, 2013; Virts et al.
2013; Peatman et al. 2015; Hagos et al. 2016; Tan et al. 2018, 2021; Specq et al. 2020), here we examined the diurnal cycle of specific humidity in the lower troposphere $(1000-700 \mathrm{hPa})$ over the $\mathrm{MC}\left(10^{\circ} \mathrm{S}-10^{\circ} \mathrm{N}, 100^{\circ}-150^{\circ} \mathrm{E}\right.$; see the boxed region in Fig. $5 \mathrm{a}$ ). At day 0 , both active and weakening MJO events featured a diurnal cycle in specific humidity, with a peak near 0800 UTC (approximately 1500 LT) and a minimum near 2200 UTC (approximately 0500 LT) (Fig. 10a). It is clear that active MJO events had greater amounts of specific humidity in the lower troposphere across the MC than did weakening events (Fig. 10a). It is also clear that the diurnal peaks of specific humidity were pronounced over land (Fig. 10c) than over ocean (Fig. 10d), even though active MJO events had more moisture over both land and ocean points (Fig. 10c, d) than 

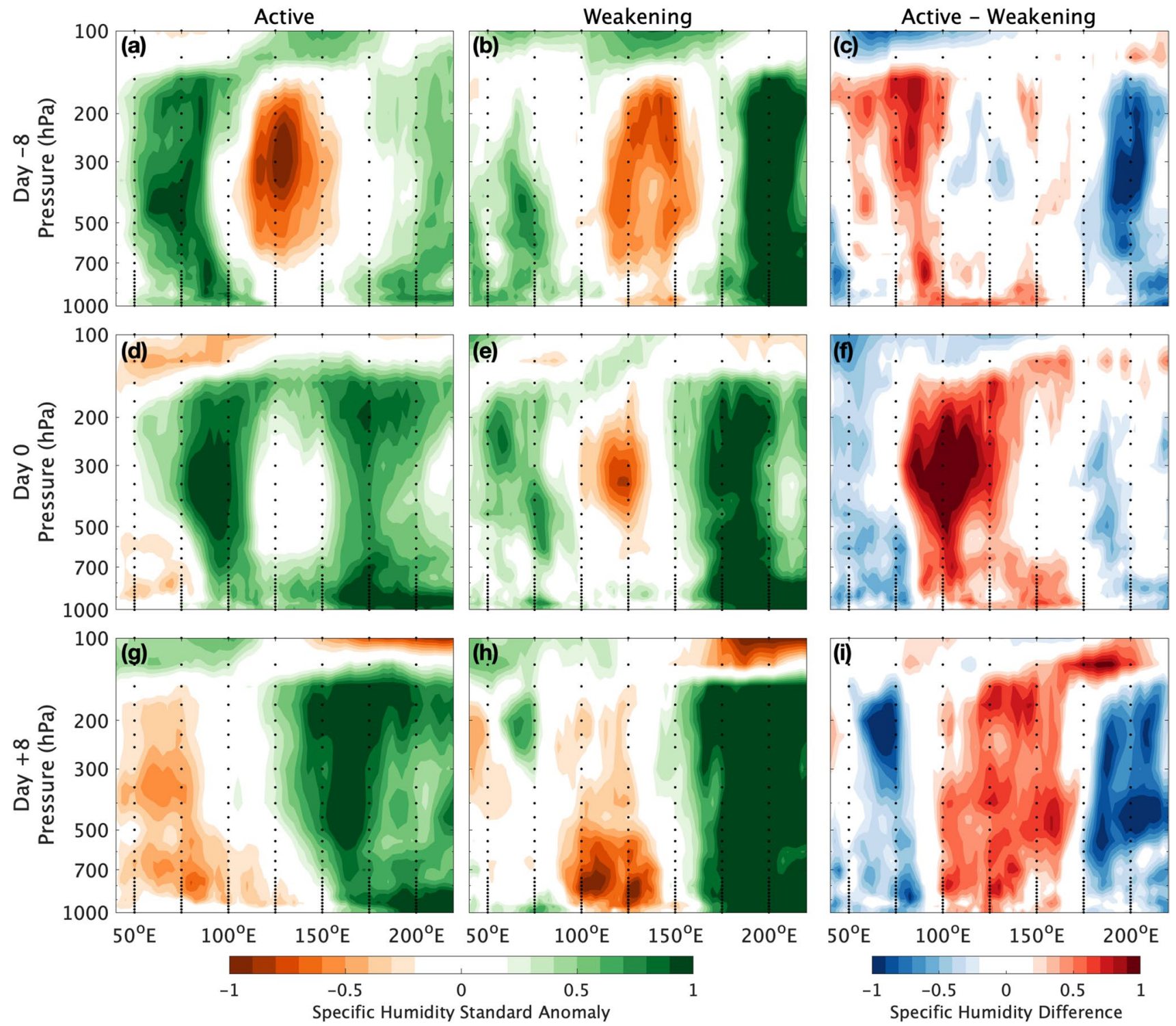

Fig. 8 As in Fig. 4, but for active and weakening MJO events during El Niño conditions

weakening events did. This moisture would be available either locally or via advection, conditions that are known to favor MJO intensity and propagation. Moreover, looking at this diurnal cycle of convection from day -20 to +15 (Fig. 10b, d), it is clear that the differences in specific humidity between active and weakening MJO events began to emerge around day -15 and peaked between day -5 and day 0 (Fig. 10b). The differences in specific humidity were statistically significant at most hours between days -7 and -4 , although the land points had statistically significantly more specific humidity than the water points did from days -10 to 0 (Fig. 10d). By day +8 , the diurnal cycles of humidity of active and weakening MJO events were similar again. Similarities in the overall shapes of the diurnal cycles between active and weakening events
(Fig. 10) suggest that in both cases, the cycles are driven by changes to background specific humidity.

\section{Conclusions}

Active and weakening MJO events were examined in four ways: index amplitude, OLR, vertical and horizontal distributions of specific humidity (including during different phases of QBO and ENSO), and diurnal cycle of specific humidity over the MC. MJO events that remained active had larger RMM and OMI index amplitudes in both indices than did weakening events. Those differences became statistically significant as early as day -3 (for the RMM) and day -8 (for the OMI). These differences in index amplitude were 

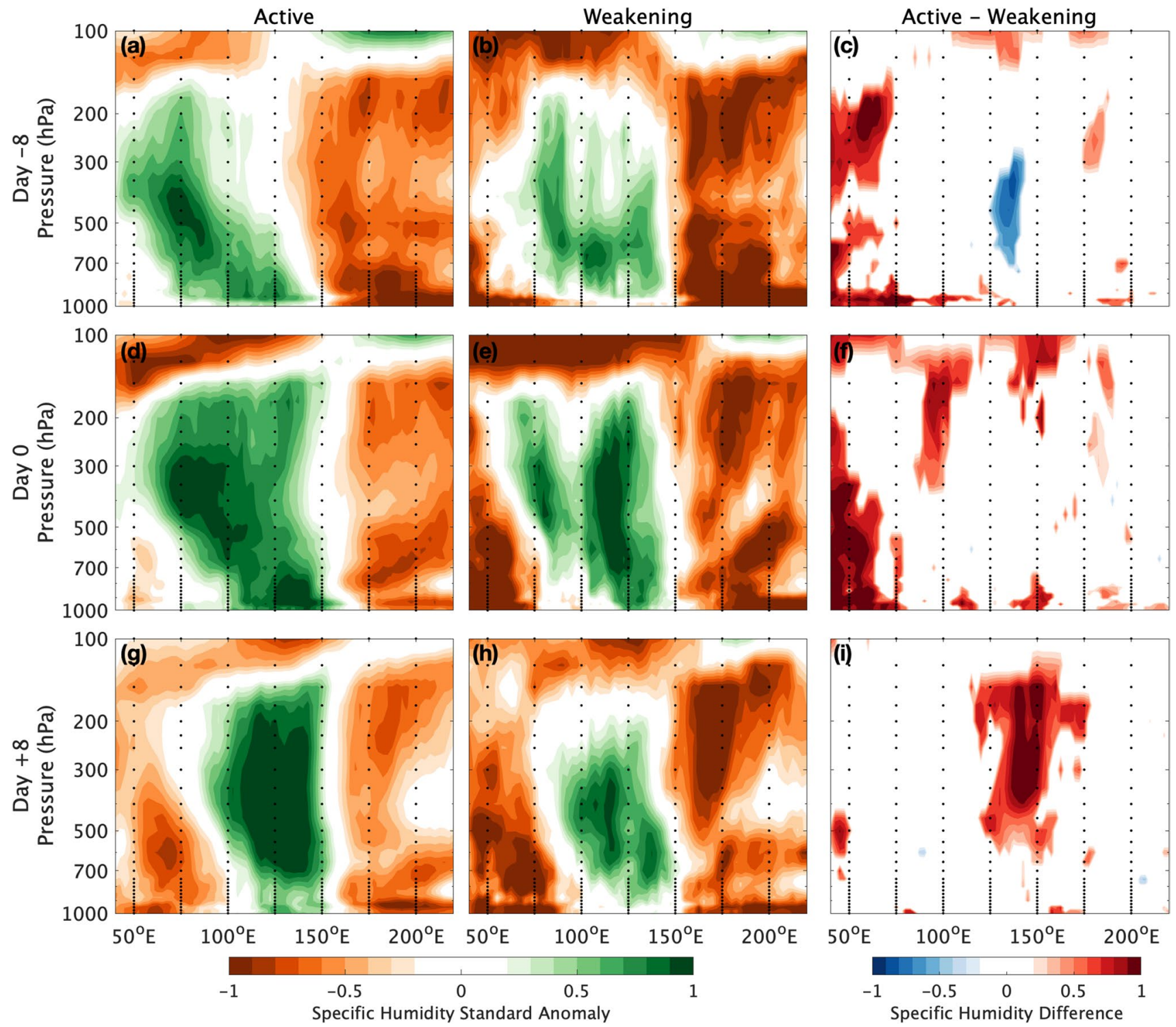

Fig. 9 As in Fig. 4, but for active and weakening MJO events during La Niña conditions

consistent with OLR, where active MJO events had stronger OLR anomalies than did weakening events. Stronger negative OLR anomalies were concentrated from $10^{\circ} \mathrm{S}-10^{\circ} \mathrm{N}$ over the Indian Ocean at day -8 , over the eastern Indian Ocean and western MC at day 0 , and eastern MC and western Pacific Ocean at day +8 , with stronger positive OLR anomalies located to both the west and east of the negative anomalies. Thus, active MJO events were stronger than weakening MJO events over the MC, and that difference was manifest in both index amplitude and OLR anomalies.

Active MJO events were characterized by greater specific humidity than weakening events, both in the convective envelope and to the east of it. At day - 8, active MJO events had more specific humidity than weakening events between $1000-200 \mathrm{hPa}$ in the region $75^{\circ}-100^{\circ} \mathrm{E}$, and between
$1000-700 \mathrm{hPa}$ in the region $100^{\circ}-150^{\circ} \mathrm{E}$. At day 0 , active MJO events had more specific humidity than weakening events over much of the eastern Indian Ocean and MC, with anomalies concentrated between $700-200 \mathrm{hPa}$ near $100^{\circ} \mathrm{E}$. By day +8 , active MJO events were much more moist than weakening ones, with specific humidity differences noted between $100^{\circ}-170^{\circ} \mathrm{E}$ over much of the troposphere. Thus, active $\mathrm{MJO}$ events that cross the MC are associated with a more humid troposphere than weakening events. This result is similar to Feng et al. (2015) and DeMott et al. (2018), who noted greater lower-level zonal moisture flux convergence in propagating $\mathrm{MJO}$ events than in weakening events.

This pattern, whereby active MJO events had greater tropospheric specific humidity than weakening events, was also seen during both easterly and westerly QBO winds and both 

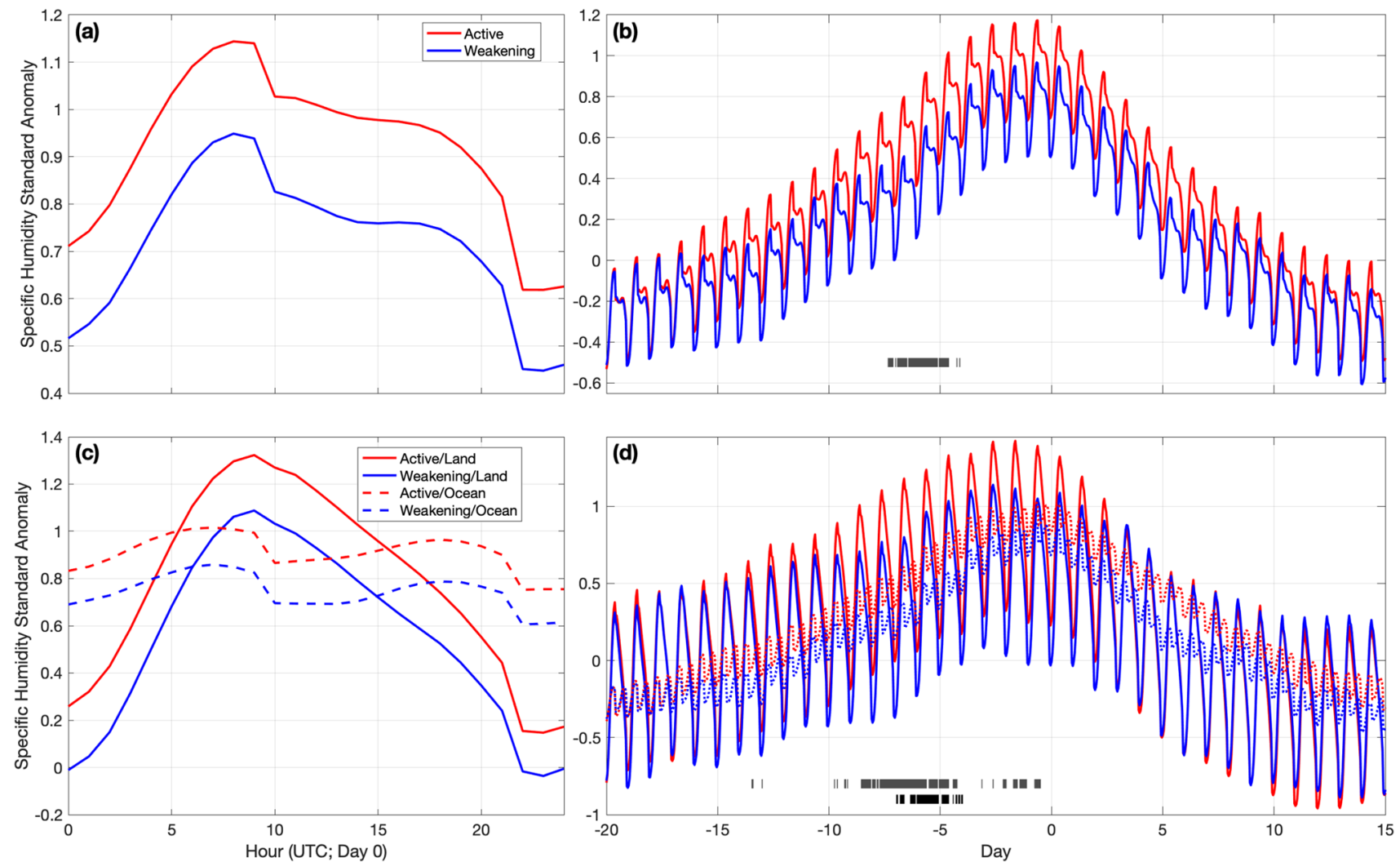

Fig. 10 Diurnal cycle of specific humidity standard anomalies for active and weakening MJO events for $\mathbf{a}$ day 0 and $\mathbf{b}$ days -20 to +15 over the MC. Anomalies are horizontally averaged over $10^{\circ} \mathrm{S}-10^{\circ}$ $\mathrm{N}, 100^{\circ}-150^{\circ} \mathrm{E}$ (boxed region in Fig. 5a) and vertically averaged from 1000 to $700 \mathrm{hPa}$. Hours where the average specific humidity for active MJO events was statistically significantly different (at the 95th percentile) from weakening events are indicated by the dark bars at

El Niño and La Niña conditions. It persisted on days -8 , 0 , and +8 . Moreover, during QBO westerly winds (which are known to inhibit MJO propagation; Zhang and Zhang 2018; Martin et al. 2019), active MJO events had greater specific humidity over the eastern Indian Ocean and western MC than did active MJO events during QBO easterly winds. This difference extended throughout the troposphere (from 1000 to $100 \mathrm{hPa}$ ), was present in both extended winter (November-March) and the entire year, and suggests that in order to propagate across the MC during QBO westerly conditions, an MJO event needs greater specific humidity in the troposphere than it does during QBO easterly winds. The greater specific humidity in both El Niño and La Niña events indicates that active MJO events are more humid than weakening MJO events during both El Niño and La Niña.

Finally, in addition to vertical cross sections and horizontal composites, the diurnal cycle of specific humidity was examined for active and weakening MJO events. Both classes of MJO events featured a pronounced diurnal cycle in specific humidity over the land points that peaked around the bottom of $(\mathbf{b})$. Anomalies in $(\mathbf{c}, \mathbf{d})$ are the same as $(\mathbf{a}, \mathbf{b})$ except specific humidity standard anomalies over land (solid curves) and ocean (dashed curves) are separated. The first row of gray bars across the bottom denotes when specific humidity over land during active events was statistically significantly different from weakening events, and the second row of gray bars denotes statistically significant differences in specific humidity for points over the ocean

1500 LT and reached a minimum around 0500 LT. However, active MJO events had greater moisture values at all hours of the day in both land and ocean points, and that moisture difference was apparent starting as early as 15 days before the MJO event reached the MC. The differences in diurnal cycle over land points were statistically significant at the $95^{\text {th }}$ percentile between days -10 and 0 . These differences in the diurnal cycle appear to be due to changes in background specific humidity. Future studies of MJO intensity and propagation across the MC may wish to consider including specific humidity in definitions of MJO strength to aid in characterizing whether an MJO event will remain active or weaken to inactive.

Author contributions BB led the writing and hypothesis design; $\mathrm{CD}$ created all figures and helped in writing; PR and ES edited the manuscript. 
Funding This research was sponsored by Office of Naval Research award N0001416WX01752 and National Science Foundation award OPP 1821915

Availability of data and material The RMM index is freely available for download from http://www.bom.gov.au/clima te/mjo/; the OMI is freely available for download from https://www.esrl.noaa.gov/psd/mjo/mjoindex/omi.1x.txt; the ERA5 reanalysis data are available from https://www. ecmwf.int/en/forecasts/datasets/reanalysis-datasets/era5; the OLR data are available from https://psl.noaa.gov/data/ gridded/data.interp_OLR.html; and the Oceanic Niño Index is available from http://origin.cpc.ncep.noaa.gov/products/ analysis_monitoring/ensostuff/ONI_v5.php.

Code availability All analyses were made using statistical and analytical packages available in MATLAB.

\section{Compliance with ethical standards}

Conflicts of interest/Competing interest The authors declare they have no conflicts of interest or competing interests.

Open Access This article is licensed under a Creative Commons Attribution 4.0 International License, which permits use, sharing, adaptation, distribution and reproduction in any medium or format, as long as you give appropriate credit to the original author(s) and the source, provide a link to the Creative Commons licence, and indicate if changes were made. The images or other third party material in this article are included in the article's Creative Commons licence, unless indicated otherwise in a credit line to the material. If material is not included in the article's Creative Commons licence and your intended use is not permitted by statutory regulation or exceeds the permitted use, you will need to obtain permission directly from the copyright holder. To view a copy of this licence, visit http://creativecommons.org/licenses/by/4.0/.

\section{References}

Adames ÁF, Kim D (2016) The MJO as a dispersive, convectively coupled moisture wave: theory and observations. J Atmos Sci 73:913-941. https://doi.org/10.1175/JAS-D-15-0170.1

Ahn M, Kim D, Ham Y, Park S (2020) Role of Maritime Continent land convection on the mean state and MJO propagation. J Clim 33:1659-1675. https://doi.org/10.1175/JCLI-D-19-0342.1

Benedict J, Randall DA (2007) Observed characteristics of the MJO relative to maximum rainfall. J Atmos Sci 64:2332-2354. https:// doi.org/10.1175/JAS3968.1

Chen X, Ling J, Li C (2016) Evolution of the Madden-Julian oscillation in two types of El Niño. J Clim 29:1919-1934. https://doi. org/10.1175/JCLI-D-15-0486.1

DeMott CA, Wolding BO, Maloney ED, Randall DA (2018) Atmospheric mechanisms for MJO decay over the Maritime Continent. J Geophys Res Atmos 123:5188-5204. https://doi. org/10.1029/2017JD026979
Densmore CR, Sanabia ER, Barrett BS (2019) QBO influence on MJO amplitude over the Maritime Continent: physical mechanisms and seasonality. Mon Weather Rev 147:389-406. https:// doi.org/10.1175/MWR-D-18-0158.1

Feng J, Li T, Zhu W (2015) Propagating and nonpropagating MJO events over the Maritime Continent. J Clim 28:8430-8449. https ://doi.org/10.1175/JCLI-D-15-0085.1

Fuchs Ž, Raymond DJ (2017) A simple model of intraseasonal oscillations. J Adv Model Earth Syst 9:1195-1211. https://doi. org/10.1002/2017MS000963

Gonzalez AO, Jiang X (2017) Winter mean lower tropospheric moisture over the Maritime Continent as a climate model diagnostic metric for the propagation of the Madden-Julian oscillation. Geophys Res Lett 44:2588-2596. https://doi.org/10.1002/2016G L072430

Hagos SM, Zhang C, Feng Z, Burleyson CD, DeMott C, Kerns B et al (2016) The impact of the diurnal cycle on the propagation of Madden-Julian Oscillation convection across the Maritime Continent. J Adv Model Earth Syst 8:1552-1564. https://doi. org/10.1002/2016MS000725

Hendon HH, Salby ML (1994) The life cycle of Madden-Julian oscillation. J Atmos Sci 51:2225-2237. https://doi.org/10.1175/15200469(1994)051\%3c2225:TLCOTM\%3e2.0.CO;2

Hendon HH, Wheeler MC, Zhang C (2007) Seasonal dependence of the MJO-ENSO relationship. J Climate 20:531-543. https://doi. org/10.1175/JCLI4003.1

Hersbach $\mathrm{H}$ et al (2020) The ERA5 global reanalysis. Q J R Meteorol Soc 146(730):1999-2049. https://rmets.onlinelibrary.wiley.com/ doi/full/10.1002/qj.3803

Hsu H-H, Lee M-Y (2005) Topographic effects on the eastward propagation and initiation of the Madden-Julian Oscillation. J Clim 18:795-809. https://doi.org/10.1175/JCLI-3292.1

Hsu P, Li T (2012) Role of the boundary layer moisture asymmetry in causing the eastward propagation of the Madden-Julian Oscillation. J Clim 25:4914-4931. https://doi.org/10.1175/JCLID-11-00310.1

Jiang X, Waliser DE, Xavier P, Zhu H (2015) Vertical structure and physical processes of the Madden-Julian Oscillation: exploring key model physics in climate simulations. J Geophys Res Atmos. https://doi.org/10.1002/2014JD022375

Jones C, Hazra A, Carvalho LM (2015) The Madden-Julian Oscillation and boreal winter forecast skill: an analysis of NCEP CFSv2 reforecasts. J Clim 28:6297-6307. https://doi.org/10.1175/ JCLI-D-15-0149.1

Kerns BW, Chen SS (2016) Large-scale precipitation tracking and the MJO over the Maritime Continent and Indo-Pacific warm pool. J Geophys Res Atmos 121:8755-8776. https://doi. org/10.1002/2015JD024661

Kikuchi K, Wang B, Kajikawa Y (2012) Bimodal representation of the tropical intraseasonal oscillation. Clim Dyn 38:1989-2000. https ://doi.org/10.1007/s00382-011-1159-1

Kiladis GN, Straub KH, Haertel PT (2005) Zonal and vertical structure of the Madden-Julian oscillation. J Atmos Sci 62:2790-2809. https://doi.org/10.1175/JAS3520.1

Kiladis GN, Dias J, Straub KH, Wheeler MC, Tulich SN, Kikuchi K et al (2014) A comparison of OLR and circulation-based indices for tracking the MJO. Mon Weather Rev 142:1697-1715. https:// doi.org/10.1175/MWR-D-13-00301.1

Kim D, Sperber K, Stern W, Waliser D, Kang IS, Maloney E et al (2009) Application of MJO simulation diagnostics to climate models. J Clim 22:6413-6436. https://doi.org/10.1175/2009J CLI3063.1

Kim D, Kug J-S, Sobel A (2014) Propagating versus nonpropagating Madden-Julian Oscillation events. J Clim 27:111-125. https://doi. org/10.1175/JCLI-D-13-00084.1 
Kim H, Kim D, Vitart F, Toma V, Kug J, Webster P (2016) MJO propagation across the Maritime Continent in the ECMWF Ensemble Prediction System. J Clim 29:3973-3988. https://doi.org/10.1175/ JCLI-D-15-0862.1

Kim D, Kim H, Lee MI (2017) Why does the MJO detour the Maritime Continent during austral summer? Geophys Res Lett 44:25792587. https://doi.org/10.1002/2017GL072643

Kim D, Maloney ED, Zhang C (2020) Review: MJO propagation over the Maritime Continent. In: Chang CP et al (eds) The multiscale global monsoon system, Vol. 11, World Scientific Series on Asia-Pacific Weather and Climate. World Scientific, Singapore (in press)

Kousky VE, Higgins RW (2007) An alert classifications system for monitoring and assessment of the ENSO cycle. Weather Forecast 22:353-371

LaFleur DM, Barrett BS, Henderson GR (2015) Some climatological aspects of the Madden-Julian Oscillation (MJO). J Clim 28:60396053. https://doi.org/10.1175/JCLI-D-14-00744.1

Lau K-M, Chan P (1986) The 40-50 day oscillation and the El Niño/ Southern Oscillation: a new perspective. Bull Am Meteorol Soc 67:533-534. https://doi.org/10.1175/1520-0477(1986)067\%3c053 3:TDOATE\%3e2.0.CO;2

Lawrence DM, Webster PJ (2002) The boreal summer intraseasonal oscillation: relationship between northward and eastward movement of convection. J Atmos Sci 59:1593-1606

Lee J-Y, Wang B, Wheeler M, Fu X, Waliser D, Kang I-S (2013) Realtime multivariate indices for the boreal summer intraseasonal oscillation over the Asian summer monsoon region. Clim Dyn 40(1-2):493-509. https://doi.org/10.1007/s00382-012-1544-4

Lee S-K, Mapes BE, Wang C, Enfield DB, Weaver SJ (2014) Springtime ENSO phase evolution and its relation to rainfall in the continental U.S. Geophys Res Lett 41:1673-1680. https://doi. org/10.1002/2013GL059137

Li T (2014) Recent advance in understanding the dynamics of the Madden-Julian Oscillation. J Meteorol Res 28(1):1-33. https:// doi.org/10.1007/s13351-014-3087-6

Li T, Wang B (1994) The influence of sea surface temperature on the tropical intraseasonal oscillation: a numerical study. Mon Wea Rev 122:2349-2362. https://doi.org/10.1175/1520-0493

Li C, Smith I (1995) Numerical simulation of the tropical intraseasonal oscillation and the effect of warm SST. Acta Meteor Sin 9:1-12

Liebmann B, Smith CA (1996) Description of a complete (interpolated) outgoing longwave radiation dataset. Bull Amer Meteorol Soc $77: 1275-1277$

Ling J, Zhang C, Joyce R, Xie P, Chen G (2019) Possible role of the diurnal cycle in land convection in the barrier effect on the MJO by the Maritime Continent. Geophys Res Lett 46:3001-3011. https://doi.org/10.1029/2019GL081962

Liu F, Chen Z, Huang G (2016a) Role of delayed deep convection in the Madden-Julian Oscillation. Theor Appl Climatol 126(1):313321. https://doi.org/10.1007/s00704-015-1587-7

Liu P, Zhang Q, Zhang C, Zhu Y, Khairoutdinov M, Kim H-M et al (2016b) A revised real-time multivariate MJO index. Mon Weather Rev 144:627-642. https://doi.org/10.1175/ MWR-D-15-0237.1

Madden RA (1986) Seasonal-variations of the 40-50 day oscillation in the tropics. J Atmos Sci 43:3138-3158

Madden RA, Julian PR (1971) Detection of a 40-50 day oscillation in the zonal wind in the tropical Pacific. J Atmos Sci 28:702-708. https://doi.org/10.1175/1520-0469(1971)028

Madden RA, Julian PR (1972) Description of global-scale circulation cells in the tropics with a 40-50-day period. J Atmos Sci 29:1109-1123. https://doi.org/10.1175/1520-0469(1972)029

Madden RA, Julian PR (1994) Observations of the 40-50 day tropical oscillation: a review. Mon Weather Rev 122:814-836. https://doi. org/10.1175/1520-0493(1994)122
Madja AJ, Yang Q (2016) A multiscale model for the intraseasonal impact of the diurnal cycle over the Maritime Continent on the Madden-Julian Oscillation. J Atmos Sci 73:579-604. https://doi. org/10.1175/JAS-D-15-0158.1

Maloney ED (2009) The moist static energy budget of a composite tropical intraseasonal oscillation in a climate model. J Clim 22:711-729. https://doi.org/10.1175/2008JCLI2542.1

Maloney ED, Hartmann DL (1998) Frictional moisture convergence in a composite life cycle of the Madden-Julian oscillation. J Clim 11:2387-2403. https://doi.org/10.1175/1520-0442(1998)011

Martin Z, Wang S, Nie J, Sobel A (2019) The impact of the QBO on MJO convection in cloud-resolving simulations. J Atmos Sci 76:669-688

Matthews AJ (2000) Propagation mechanisms for the Madden-Julian Oscillation. Q J R Meteorol Soc 126:2637-2651. https://doi. org/10.1002/qj.49712656902

Oh K, Kim K, Lim G (2012) Impact of MJO on the diurnal cycle of rainfall over the western Maritime Continent in the austral summer. Clim Dyn 38:1167-1180. https://doi.org/10.1007/s0038 2-011-1237-4

Oh J, Kim B, Kim K et al (2013) The impact of the diurnal cycle on the MJO over the Maritime Continent: a modeling study assimilating TRMM rain rate into global analysis. Clim Dyn 40:893-911. https://doi.org/10.1007/s00382-012-1419-8

Peatman SC, Matthews AJ, Stevens DP (2014) Propagation of the Madden-Julian Oscillation through the Maritime Continent and scale interaction with the diurnal cycle of precipitation. Q J R Meteorol Soc 140:814-825. https://doi.org/10.1002/qj.2161

Peatman SC, Matthews AJ, Stevens DP (2015) Propagation of the Madden-Julian Oscillation and scale interaction with the diurnal cycle in a high-resolution GCM. Clim Dyn 45(9-10):29012918. https://doi.org/10.1007/s00382-015-2513-5

Pillai PA, Chowdary JS (2016) Indian summer monsoon intra-seasonal oscillation associated with the developing and decaying phase of El Niño. Int J Climatol 36:1846-1862. https://doi. org/10.1002/joc. 4464

Pohl B, Matthews AJ (2007) Observed changes in the lifetime and amplitude of the Madden-Julian oscillation associated with interannual ENSO sea surface temperature anomalies. J Clim 20:2659-2674. https://doi.org/10.1175/JCLI4230.1

Qian J-H (2008) Why precipitation is mostly concentrated over islands in the Maritime Continent. J Atmos Sci 65:1428-1441. https://doi.org/10.1175/2007JAS2422.1

Ramage CS (1968) Role of a tropical "Maritime Continent" in the atmospheric circulation. Mon Weather Rev 96:365-370. https ://doi.org/10.1175/1520-0493(1968)096

Rauniyar S, Walsh K (2011) Scale interaction of the diurnal cycle of rainfall over the Maritime Continent and Australia: influence of the MJO. J Clim 24:325-348. https://doi.org/10.1175/2010J CLI3673.1

Ray P, Zhang C, Moncrieff MW, Dudhia J, Caron JM, Leung LR et al (2011) Role of the atmospheric mean state on the initiation of the Madden-Julian Oscillation in a tropical channel model. Clim Dyn 36L:161-184. https://doi.org/10.1007/s000382-010-0859-2

Ray P, Zhang C, Dudhia J, Li T, Moncrieff MW (2012) Tropical channel model. In: Druyan LM (ed) Climate models. InTech Open Access Pub, London, pp 3-18

Raymond DJ, Fuchs Z (2009) Moisture modes and the MaddenJulian Oscillation. J Clim 22(11):3031-3046

Roundy PE, Schreck CJ, Janiga MA (2009) Contributions of convectively coupled equatorial Rossby waves and Kelvin waves to the Real-Time Multivariate MJO indices. Mon Weather Rev 137:469-478. https://doi.org/10.1175/2008MWR2595.1

Rui H, Wang B (1990) Development characteristics and dynamic structure of tropical intraseasonal convection anomalies. J Atmos Sci 47:357-379 
Salby ML, Garcia R, Hendon HH (1994) Planetary-scale circulations in the presence of climatological and waveinduced heating. J Atmos Sci 51:2344-2367. https://doi. org/10.1175/1520-0469(1994)051

Seo KH, Wang W, Gottschalck J, Zhang Q, Schemm J-K, Higgins W et al (2009) Evaluation of MJO forecast skill from several statistical and dynamical forecast models. J Clim 22:2372-2388. https:// doi.org/10.1175/2008JCLI2421.1

Sobel AH, Maloney ED (2012) An idealized semi-empirical framework for modeling the Madden-Julian oscillation. J Atmos Sci 69(5):1691-1705

Sobel AH, Maloney ED (2013) Moisture modes and the eastward propagation of the MJO. J Atmos Sci 70:187-192. https://doi. org/10.1175/JAS-D-12-0189.1

Specq D, Bellon G, Peltier A, Lefèvre J, Menkes C (2020) Influence of subseasonal variability on the diurnal cycle of precipitation on a mountainous island: the case of New Caledonia. Mon Weather Rev 148:333-351. https://doi.org/10.1175/MWR-D-19-0177.1

Sperber KR (2003) Propagation and the vertical structure of the Madden-Julian Oscillation. Mon Weather Rev 131:3018-3037. https://doi.org/10.1175/1520-0493(2003)131\%3c3018:PATVS $\mathrm{O} \% 3 \mathrm{e} 2.0 . \mathrm{CO} ; 2$

Stachnik JP, Waliser DE, Majda AJ (2015) Precursor environmental conditions associated with the termination of Madden-Julian Oscillation events. J Atmos Sci 72:1908-1931. https://doi. org/10.1175/JAS-D-14-0254.1

Straub KH (2013) MJO initiation in the Real-Time Multivariate MJO index. J Clim 26:1130-1151. https://doi.org/10.1175/JCLID-12-00074.1

Suematsu T, Miura H (2018) Zonal SST differences as a potential environmental factor supporting the longevity of the MaddenJulian oscillation. J Clim 31:7549-7564. https://doi.org/10.1175/ JCLI-D-17-0822.1

Tan H, Ray P, Barrett BS, Tewari M, Moncrieff MW (2018) Role of topography on the MJO in the Maritime Continent: a numerical case study. Clim Dyn. https://doi.org/10.1007/s00382-018-4275-3

Tan H, Ray P, Barrett BS, Dudhia J, Moncrieff MW (2021) Systematic patterns in land precipitation due to convection in neighboring islands in the Maritime Continent during MJO propagation. J Geophys Res Atmos 126:e2020JD033465. https://doi. org/10.1029/2020JD033465 (early online release)

Tang Y, Yu B (2008) MJO and its relationship to ENSO. J Geophys Res 113:D14106. https://doi.org/10.1029/2007JD009230

Tian B, Waliser DE, Fetzer EJ (2006) Modulation of the diurnal cycle of tropical deep convective clouds by the MJO. Geophys Res Lett 33:L20704. https://doi.org/10.1029/2006GL027752

Ventrice MJ, Wheeler MC, Hendon HH, Schreck CJ III, Thorncroft CD, Kiladis GN (2013) A modified multivariate Madden-Julian oscillation index using velocity potential. Mon Weather Rev 141:4197-4210. https://doi.org/10.1175/MWR-D-12-00327.1

Virts KS, Wallace JM, Hutchins ML, Holzworth RH (2013) Diurnal lightning variability over the Maritime Continent: Impact of lowlevel winds, cloudiness and the MJO. J Atmos Sci 70:3128-3146. https://doi.org/10.1175/JAS-D-13-021.1

Vitart F, Molteni F (2010) Simulation of the Madden-Julian oscillation and its teleconnections in the ECMWF forecast system. Q J R Meteorol Soc 136(649):842-855. https://doi.org/10.1002/qj.623

Waliser DE (2006) Intraseasonal variability. In: Wang B (ed) The Asian monsoon. Springer, Berlin, pp 203-258
Wang B, Chen G (2016) A general theoretical framework for understanding essential dynamics of Madden-Julian oscillation. Clim Dyn. https://doi.org/10.1007/s00382-016-3448-1

Wang B, Rui H (1990) Synoptic climatology of transient tropical intraseasonal convection anomalies: 1975-1985. Meteorol Atmos Phys $44: 43-61$

Wang B, Xie X (1997) A model for the boreal summer intraseasonal oscillation. J Atmos Sci 54:72-86

Wang B, Liu F, Chen G (2016) A trio-interaction theory for MaddenJulian Oscillation. Geosci Lett. https://doi.org/10.1186/s4056 2-016-0066-Z

Wei Y, Ren H (2019) Modulation of ENSO on fast and slow MJO modes during boreal winter. J Clim 32:7483-7506. https://doi. org/10.1175/JCLI-D-19-0013.1

Wheeler MC, Hendon HH (2004) An all-season real-time multivariate MJO index: development of an index for monitoring and prediction. Mon Weather Rev 132:1917-1932. https://doi. org/10.1175/1520-0493(2004)132

Wu C-H, Hsu H-H (2009) Topographic influence on the MJO in the Maritime Continent. J Clim 22:5433-5448. https://doi. org/10.1175/2009JCLI2825.1

Wu R, Song L (2018) Spatiotemporal change of intraseasonal oscillation intensity over the tropical Indo-Pacific Ocean associated with El Niño and La Niña events. Clim Dyn 50:1221-1242. https://doi. org/10.1007/s00382-017-3675-0

Zhang C (2005) Madden-Julian oscillation. Rev Geophys. https://doi. org/10.1029/2004RG000158

Zhang C (2013) Madden-Julian Oscillation: bridging weather and climate. Bull Am Meteorol Soc 94:1849-2187. https://doi. org/10.1175/BAMS-D-12-00026.1

Zhang C, Hendon HH (1997) Propagating and standing components of the intraseasonal oscillation in tropical convection. J Atmos Sci 54(6):741-752. https://doi.org/10.1175/15200469(1997)054\%3c0741:PASCOT\%3e2.0.CO;2

Zhang C, Gottschalck J (2002) SST anomalies of ENSO and the Madden-Julian oscillation in the equatorial Pacific. J Clim 15:2429 2445. https://doi.org/10.1175/1520-0442(2002)015\%3c242 9:SAOEAT\%3e2.0.CO;2

Zhang C, Ling J (2017) Barrier effect of the Indo-Pacific Maritime Continent on the MJO: perspectives from tracking MJO precipitation. J Clim 30(9):3439-3459. https://doi.org/10.1175/ JCLI-D-16-0614.1

Zhang C, Zhang B (2018) QBO-MJO connection. J Geophys Res Atmos 123:2957-2967. https://doi.org/10.1002/2017JD028171

Zhang C, Adames ÁF, Khouider B, Wang B, Yang D (2020) Four theories of the Madden-Julian Oscillation. Rev Geophys 58:e2019RG000685. https://doi.org/10.1029/2019RG000685

Zhu J, Wang W, Kumar A (2017) Simulations of MJO propagation across the Maritime Continent: impacts of SST feedback. J Climate 30:1689-1704. https://doi.org/10.1175/JCLI-D-16-0367.1

Publisher's Note Springer Nature remains neutral with regard to jurisdictional claims in published maps and institutional affiliations. 